\title{
Conservation and Sustainable Development of World Cultural Landscape Heritage in Mount Wutai
}

\begin{abstract}
Jinyu Zhang
School of Environment, Education and Development, University of Manchester, Manchester, The United Kingdom

Email: 707296116@qq.com

ABSTRACT

As of June 2021, there are 114 cultural landscape heritage sites in the world, of which mountain landscape heritage accounts for about $17.5 \%$ of the total number of cultural landscape heritage sites in the world. China joined the World Heritage Convention in 1985, and now has a total of 55 heritage sites, including 5 cultural landscape heritage sites. 2009, Mount Wutai was listed as a World Cultural Landscape Heritage. This paper analyzes the World Cultural Landscape Heritage of Wutai Mountain, finds the shortcomings in the current tourism situation, tourism image perception, and transportation conditions, and puts forward targeted suggestions to protect and sustain the development of Wutai Mountain cultural landscape driven by tourism, and provides certain reference significance for other heritage sites.
\end{abstract}

Keywords: World Cultural Landscape Heritage, Mount Wutai, Tourism Status, Conservation and Development.

\section{INTRODUCTION}

The Convention for the Protection of the World Cultural and Natural Heritage was officially adopted by UNESCO in Paris in 1972, defining and classifying World Heritage in the form of a law and a convention, which is the fundamental law for the protection of World Heritage $^{[1]}$. The concept of cultural landscapes was introduced at the 16th session of the UNESCO World Heritage Committee in Santa Fe, USA, in December 1992, and was incorporated into the World Heritage List $^{[2]}$. Cultural landscapes represent "the joint work of nature and human beings", reflecting the role of human beings in the natural environment and the harmonious coexistence with nature ${ }^{[3]}$.At present, there are 114 cultural landscapes in the world, five of which are transboundary and three of which are also listed as endangered.
China's world heritage is rich in resources and complete in variety. At present, China has a total of 55 heritage items, which is tied with Italy for the first place in terms of the number of heritage items, among which, 14 are natural heritage items, 37 are cultural heritage items (including cultural landscape heritage), and 4 are dual cultural and natural heritage items. There are only 5 cultural landscape heritage sites (Mount Lushan National Park, Mount Wutai, Hangzhou West Lake Cultural Landscape, Honghe Hani Terraces Cultural Landscape, and Zuojiang Huashan Rock Art Cultural Landscape), accounting for about $9 \%$ of China's total world heritage sites. 2009, Mount Wutai was recognized by UNESCO as a World Heritage Site in the cultural landscape category. Wutai Mountain is a sacred Buddhist mountain and a national geological park with 41 cultural landscapes ${ }^{[2] \text {, }}$ which have rich tourism value. 


\section{STATUS OF WORLD CULTURAL LANDSCAPE HERITAGE}

There are 114 cultural landscape heritage sites in the world, located in 62 countries, and about $47 \%$ of the cultural landscape heritage sites are located in Europe. There are various types of cultural landscape heritage, such as religious heritage, industrial heritage, mountainous landscape, etc. Mountain landscape heritage accounts for about $17.5 \%$ of the total cultural landscape heritage in the world. 8 mountain landscape heritage sites are selected from each continent and briefly introduced below.

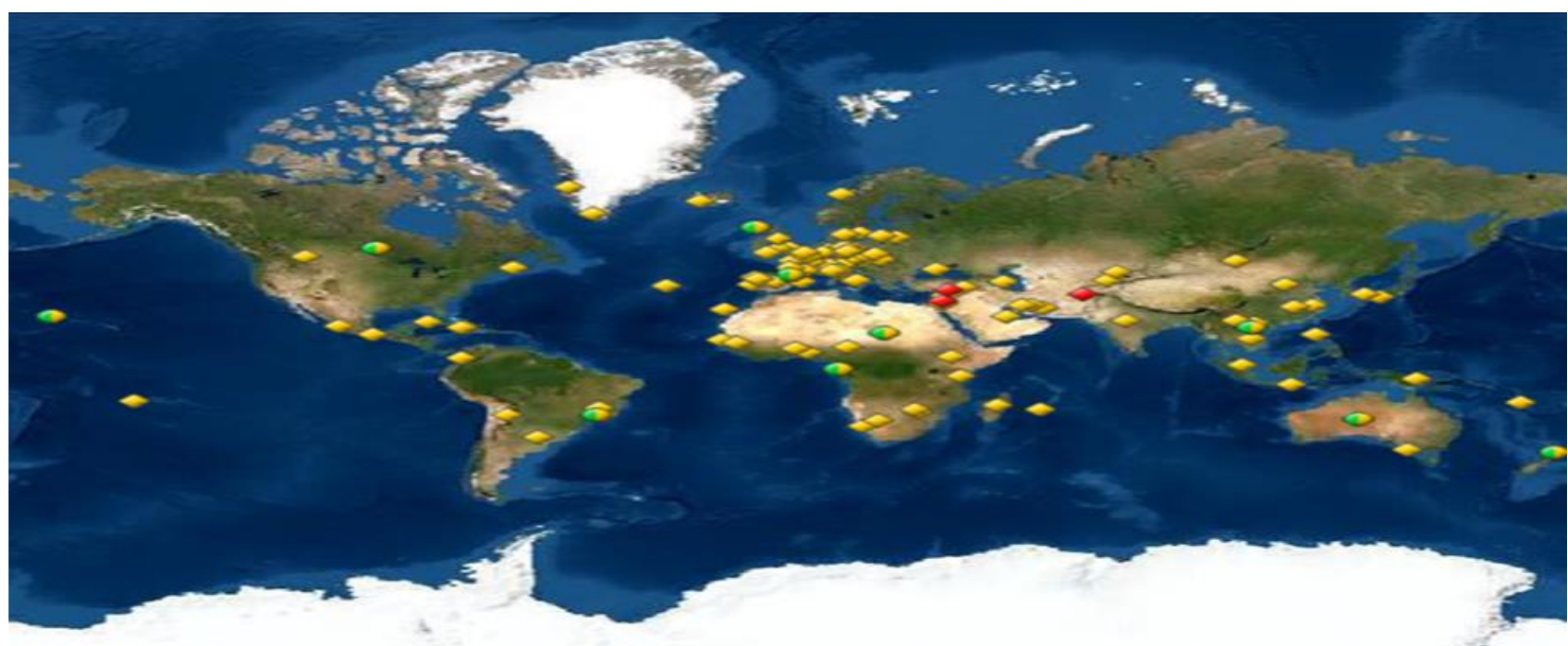

Figure 1. World Cultural Landscape Heritage Distribution Map

Table 1. Introduction of mountain landscape heritage

\begin{tabular}{cccc}
\hline Name & Country & $\begin{array}{c}\text { Date of } \\
\text { Inscription }\end{array}$ & Criteria \\
Mount Wutai & China & 2009 & (ii)(iii)(iv)(vi) \\
Sacred Sites & & & \\
and & & & \\
Pilgrimage & Japan & & \\
Routes in the & & & \\
Kii Mountain & & & \\
Range & & 2004 & \\
The Madriu- & & & (iii)(iv)(vi) \\
Perafita- & Andorra & & \\
Claror Valley & & 2004 & \\
& & & \\
Val d'Orcia & Italy & &
\end{tabular}

Located at $113^{\circ} 33^{\prime} 48^{\prime \prime} \mathrm{E}$ and $39^{\circ} 1^{\prime} 50^{\prime \prime} \mathrm{N}$. The core area is 18,415 ha and the buffer area is 42,312 ha. It is a national geological park and the first of the four famous Buddhist mountains in China.

Located at $135^{\circ} 46^{\prime} 35^{\prime \prime} \mathrm{E}$ and $33^{\circ} 50^{\prime} 13^{\prime \prime} \mathrm{N}$, the core area is 506.4 ha and the buffer area is 12,100 ha. The main area is a fusion of Shintoism and Buddhism, witnessed by three Buddhist temples on Mount Takano, Mount Yoshino and Mount Kanamine.

Located at $1^{\circ} 35^{\prime} 44^{\prime \prime} \mathrm{E}, 42^{\circ} 29^{\prime} 41^{\prime \prime} \mathrm{N}$, the core area is 4,247 ha. This canyon is a reflection of an ancient public system of land management that has existed for 700 years.

Located at $11^{\circ} 33^{\prime} \mathrm{E}, 43^{\circ} 04^{\prime} \mathrm{N}$, the heritage site covers an area of 61,187.9609 ha, with a buffer zone of 5,660.0771 ha. It is an area of combined historical, artistic, architectural and environmental characteristics, which showcases the 


\begin{tabular}{|c|c|c|c|}
\hline Matobo Hills & Zimbabwe & 2003 & $(\mathrm{iii})(\mathrm{v})(\mathrm{vi}$ \\
\hline \multicolumn{4}{|l|}{ Viñales } \\
\hline Valley & Cuba & 1999 & (iv) \\
\hline \multicolumn{4}{|l|}{ Rio de } \\
\hline \multicolumn{4}{|l|}{ Janeiro, } \\
\hline \multicolumn{4}{|l|}{ Carioca } \\
\hline Landscapes & Brazil & 2012 & (v)(vi) \\
\hline \multicolumn{4}{|l|}{ between the } \\
\hline \multirow{2}{*}{\multicolumn{4}{|c|}{$\begin{array}{l}\text { Mountain and } \\
\text { the Sea }\end{array}$}} \\
\hline & & & \\
\hline \multicolumn{4}{|l|}{ Budj Bim } \\
\hline Cultural & Australia & 2019 & (iii)(v) \\
\hline Landscape & & & \\
\hline
\end{tabular}

agricultural beauty of the Renaissance and has been an essential destination for pilgrims to Rome since the Middle Ages.

Located at $28^{\circ} 30^{\prime} \mathrm{E}, 20^{\circ} 30^{\prime} \mathrm{S}$, it has a heritage area of 205,000 ha and a buffer zone of 105,000 ha. It is one of the richest rock formations and is a meeting place for rock art. Located at $183^{\circ} 43^{\prime} 0.12^{\prime \prime} \mathrm{W}, 22^{\circ} 37^{\prime} 0.12^{\prime \prime} \mathrm{N}$, the core area is 13,200 ha. The valley landscape, exposed rocks, tobacco farming, farms and local architecture blend together.

Located at $43^{\circ} 17^{\prime} 29^{\prime \prime} \mathrm{W}, 22^{\circ} 56^{\prime} 52^{\prime \prime} \mathrm{S}$. The core area is $7,248.78$ ha and the buffer area is $8,621.38$ ha. It has a botanical garden, a famous statue of Christ, and a large number of designed landscapes.

Located at $141^{\circ} 53^{\prime} 7^{\prime \prime}$ E, $38^{\circ} 4^{\prime} 52^{\prime \prime} \mathrm{S}$, the core area covers 9,935 ha, including Bugibim Volcano, Lake Kanda, wetlands and swamps, one of the world's largest and oldest aquaculture networks.

Note: Relevant data refer to the UNESCO World Heritage Committee website at http://whc.unesco.org/.

\section{OVERVIEW OF THE CULTURAL LANDSCAPE HERITAGE OF WUTAI MOUNTAIN}

\subsection{Location}

Mount Wutai is located in Xinzhou City, northeastern Shanxi Province, spanning Wutai County, Fanshi County, Dai County, Yuanping City, and Dingxiang County, between latitude $38^{\circ} 55^{\prime}-39^{\circ} 66^{\prime} \mathrm{N}$ and longitude $113^{\circ} 29^{\prime}-$ $113^{\circ} 39^{\prime} E^{[4]}$. It belongs to the northern end of the Taihang Mountain System, and is the highest mountain in the North China Plain, with the It is the highest peak in the North China Plain and is known as the "Roof of North China"

\subsection{Mount Wutai Cultural Landscape Heritage}

Value.

Mount Wutai is the first of the four most famous

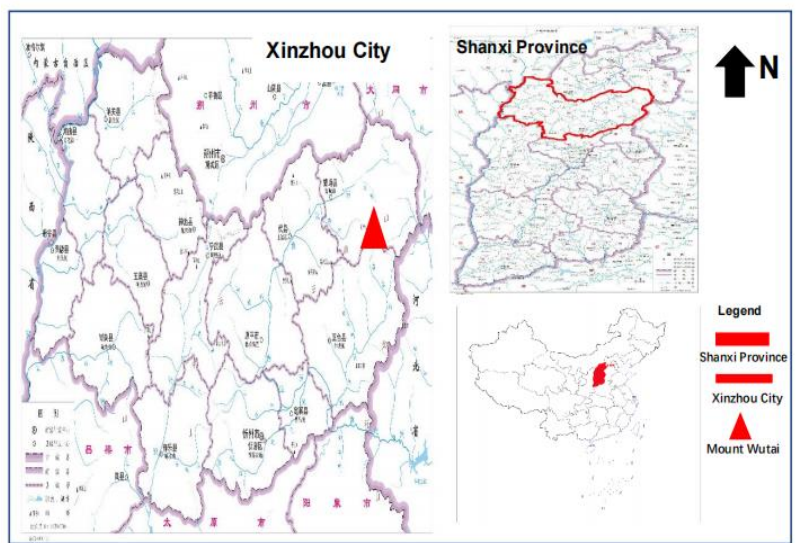

Figure 2. Location of Mount Wutai

Buddhist mountains in China, a national geological park and a treasure house of ancient Chinese architecture and art. There are as many as 41 cultural landscapes in the area, and Buddhist culture is fully integrated with nature ${ }^{[5]}$, which has a rich cultural landscape heritage value. 
Table 2. Table of cultural landscape heritage values of Mount Wutai

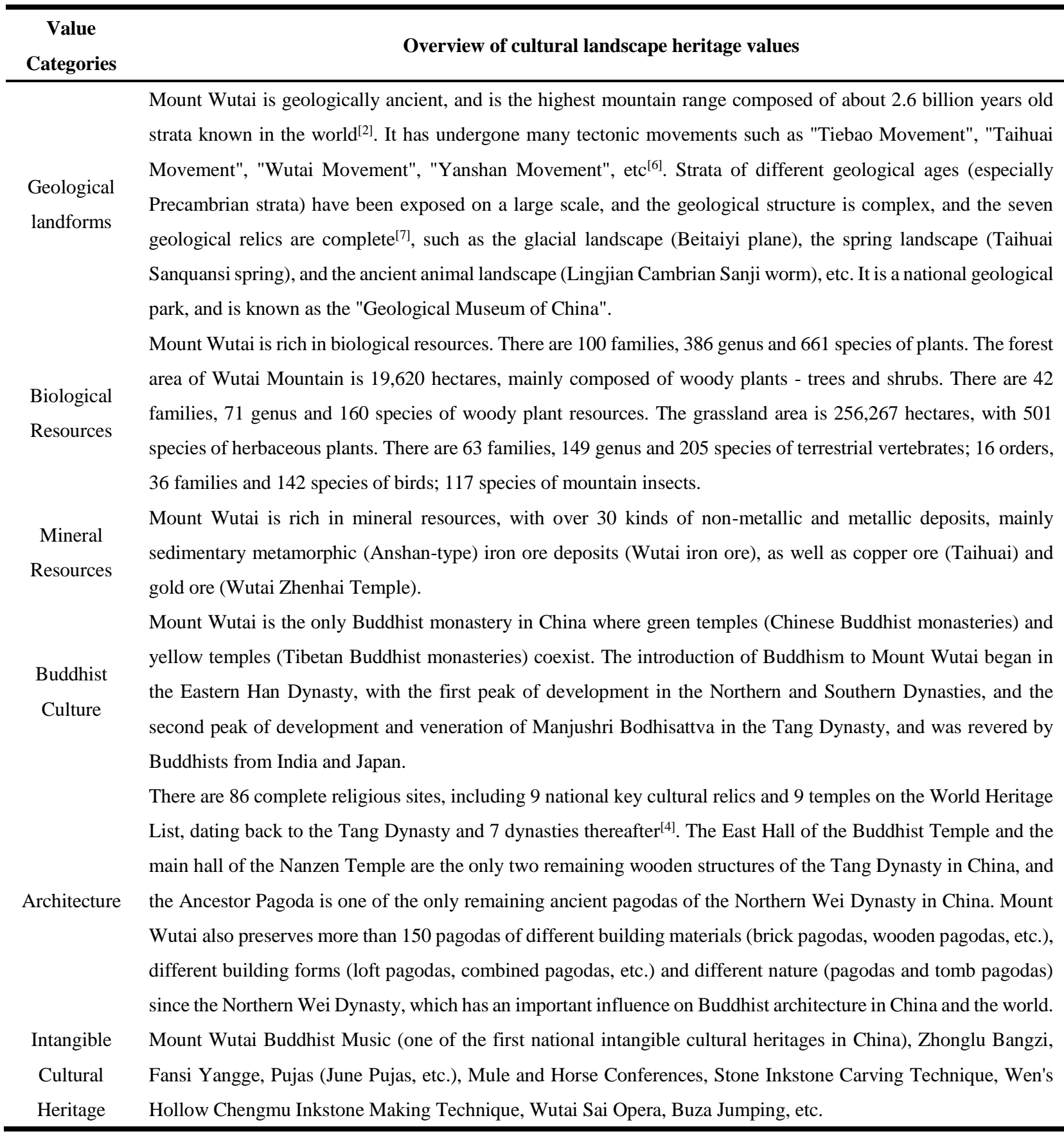

Note: Relevant data refer to the website of Mount Wutai Scenic Spot Management Committee http://wts.sxxz.gov.cn/zjxfq/.

\section{ANALYSIS OF TOURISM DEVELOPMENT IN MOUNT WUTAI}

\subsection{Analysis of tourism situation in Mount Wutai.}

Since Mount Wutai was listed as a World Cultural Landscape Heritage in 2009, the tourism reception of Mount Wutai has gradually increased and the tourism revenue has been improving. However, compared with Lushan National Park, which is also listed as a World Cultural Landscape Heritage, there is a large gap between the tourism reception and income of Mount Wutai. In addition, according to the data of Mount Wutai Scenic Spot Management Committee, it can also be known that there is a clear tourism off-peak season in Mount Wutai ${ }^{[8]}$, which is known as a cool destination with relatively large number of tourists in summer. 


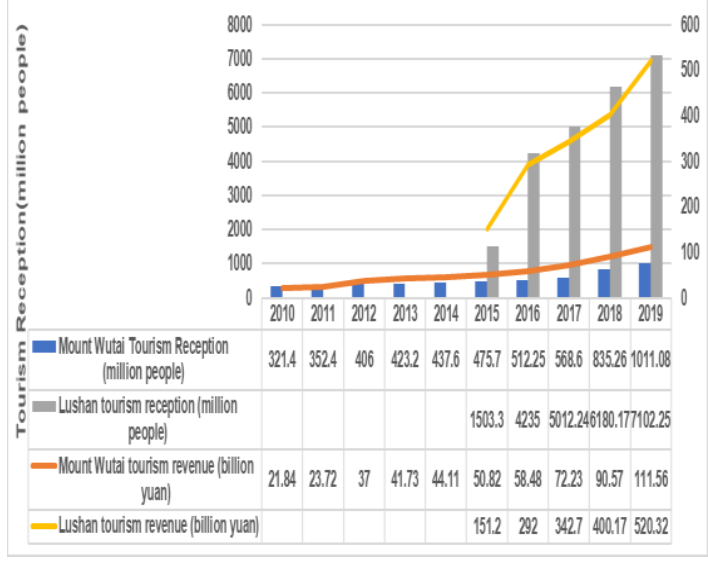

Figure 3. Comparison of tourism status between Mount Wutai and Lushan National Park

\subsection{Analysis of tourism image perception of} Mount Wutai.

Ctrip is a famous travel website in China ${ }^{[9]}$. This paper selects 100 travelogues from Ctrip, extracts relevant keywords, and summarizes the number of travelogues containing keywords. The results obtained through statistical analysis show that although Mount Wutai is a cultural landscape heritage, the impression and understanding of tourists about Wutai Mountain are mostly focused on the famous Buddhist mountain and ancient architecture, but not on the natural resources of Mount Wutai, which indicates that the tourism image of Mount Wutai is not comprehensive enough and the tourism structure is single.

\subsection{Mount Wutai Visitor Satisfaction Analysis}

Tourists are more satisfied with the attractions and food in Mount Wutai, while they are less satisfied with

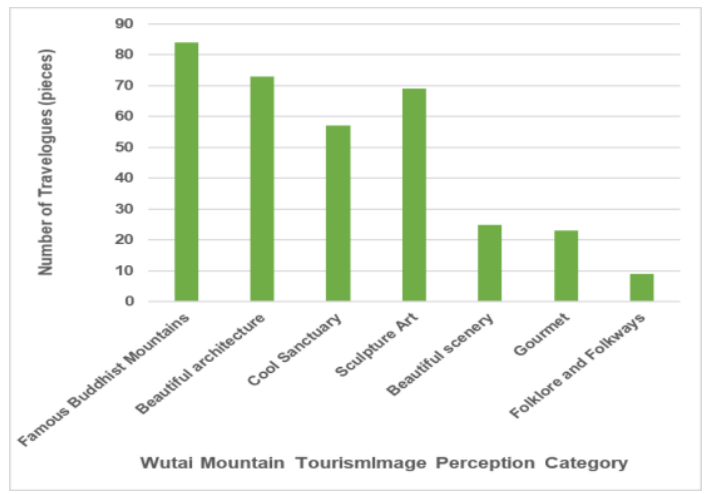

Figure 4. Tourism image perception of Mount Wutai the transportation and accommodation. After the questionnaire survey, the problem of accommodation conditions in Mount Wutai is mainly reflected in the high cost of accommodation. Tourists' satisfaction with the transportation conditions of Mount Wutai is the lowest, mainly due to the low number of direct trips to Wutai Mountain from inside and outside Shanxi Province and the long distance from the core scenic area of Mount Wutai to the top of the five platforms. In addition, most of the tourists think that Mount Wutai has a single type of tourist souvenirs, most of which are related to Buddhism, while there are relatively few souvenirs of Mount Wutai specialty products.

Table 3: Analysis of tourist satisfaction in Mount Wutai

\begin{tabular}{cccc}
\hline $\begin{array}{c}\text { Survey } \\
\text { Content }\end{array}$ & $\begin{array}{c}\text { Satisfactio } \\
\mathbf{n}(\%)\end{array}$ & $\begin{array}{c}\text { General } \\
\text { Satisfactio } \\
\mathbf{n}(\%)\end{array}$ & $\begin{array}{c}\text { Dissatisfie } \\
\mathbf{d}(\%)\end{array}$ \\
\hline $\begin{array}{c}\text { Tourist } \\
\text { Attractions } \\
\text { Accommodatio }\end{array}$ & 77.8 & 20.6 & 1.6 \\
n & 45.3 & 39.8 & 14.9 \\
Transportation & 20.6 & 59.2 & 20.2 \\
Food & 56.5 & 39.3 & 4.2 \\
Tourist & 28.6 & 55.7 & 15.7 \\
Souvenirs & & & \\
\hline
\end{tabular}

\subsection{Analysis of visitor unit price in Mount Wutai}

From August 1st to August 20th is the peak period ofdomestic tourism in China, and the average spending on accommodation and transportation costs of Mount Wutai and Lushan National Park (Beijing, Shanghai, Guangzhou and Shenzhen as an example) are queried for the reference period. By comparing and analyzing, the total per capita spending in Mount Wutai is much larger than the total per capita spending in Lushan National Park. In terms of accommodation and transportation, the average spending in Mount Wutai is also larger than the average spending in Lushan. The overall unit price of visitors to Mount Wutai is greater than the unit price of visitors to Lushan. The increase in the unit price of tourists will reduce the attractiveness of tourists, and the rate of repeat visits will be reduced, and the tourism revenue of the site will be reduced accordingly. 
Table 4: Analysis of visitor unit price in Mount Wutai

\begin{tabular}{ccccccc}
\hline & $\begin{array}{c}\text { Total spending per } \\
\text { capita (tourism } \\
\text { revenue/visitor } \\
\text { arrivals) (2019) }\end{array}$ & $\begin{array}{c}\text { Accommod } \\
\text { ation } \\
\text { (Yuan) }\end{array}$ & $\begin{array}{c}\text { Beijing - } \\
\text { Destinatio } \\
\mathbf{n} \text { (Yuan) }\end{array}$ & $\begin{array}{c}\text { Shanghai - } \\
\text { Destinatio } \\
\text { (yuan) }\end{array}$ & $\begin{array}{c}\text { Guangzho } \\
\text { u - } \\
\text { Destination } \\
\text { (yuan) }\end{array}$ & $\begin{array}{c}\text { Shenzhen - Destination } \\
\text { (yuan) }\end{array}$ \\
\hline $\begin{array}{c}\text { Mount } \\
\text { Wutai }\end{array}$ & 1103.5 & 607.6 & 224.5 & 499.9 & 568.3 & 603.9 \\
$\begin{array}{c}\text { Lushan } \\
\text { National } \\
\text { Park }\end{array}$ & 732.6 & 327.6 & 473.0 & 372.5 & 511.4 & 443.8 \\
\hline
\end{tabular}

\section{MOUNT WUTAI CONSERVATION AND SUSTAINABLE DEVELOPMENT RECOMMENDATIONS}

\subsection{Improve traffic accessibility and tourism service facilities.}

There are 114 cultural landscape heritage sites in the world, 3 of which are listed as endangered, and the Elbe Valley in Germany was delisted in 2009 due to the destruction of the landscape by new construction in the core area, which shows that there is a long way to go to protect the cultural landscape heritage. The conservation status of ancient buildings in Mount Wutai is not optimistic. There were more than 200 temples in the Northern Qi Dynasty, more than 360 in the Tang Dynasty, 72 remaining in the Song Dynasty, 104 in the Ming Dynasty, 112 in the late Qing Dynasty, and only 86 relatively intact places of religious activities remain ${ }^{[4]}$. Mount Wutai should increase the protection of ancient buildings and reduce the construction of too many new buildings. Increase the publicity, education and legal protection of the cultural landscape heritage of Mount Wutai and raise people's awareness of the protection of world heritage.

\subsection{Improve traffic accessibility and tourism service facilities.}

The five tops of Mount Wutai are far away from the core area of Taihuai Town and are not easily accessible, resulting in many attractions that tourists cannot stroll around, in addition to fewer direct trips to Mount Wutai, which to a certain extent affects the development of tourism in Mount Wutai. Mount Wutai should strengthen the accessibility of the transportation network within the attractions, increase the number of roads to key attractions (such as the Buddha Light Temple) and increase the number of sightseeing buses. At the same time, basic tourism service facilities such as tourist service centers, rest areas and public restrooms in Mount Wutai should be continuously improved to meet the needs of tourists. Many accommodations in the core scenic area of Taihuai Town are too close to the attractions ${ }^{[10]}$, which threatens the cultural landscape heritage of Mount Wutai, and the world heritage should be protected while improving tourism service facilities.

\subsection{Explore the tourism value of world cultural landscape heritage and improve heritage tourism structure.}

Tourists' perception of Mount Wutai is concentrated on the cultural aspects, and they do not have a deep understanding of the natural aspects, which to some extent causes the singularity of the source structure ${ }^{[1]}$. We should deeply explore the tourism value, combine the value of cultural landscape heritage, improve the structure of heritage tourism ${ }^{[12]}$, attract more tourists from the source, create the image of ecological tourism ${ }^{[13]}$ and geological tourism in Mount Wutai, and promote the sustainable development of Mount Wutai. In addition, the construction of Mount Wutai tourism website should be strengthened to improve the tourism image of Mount Wutai and improve the tourism structure of the heritage site $^{[14]}$. 


\subsection{Reasonable price adjustment to improve the attractiveness of tourism in Mount Wutai.}

Mount Wutai should regulate the higher phenomena of accommodation, transportation and entrance fees, provide certain consumption subsidies for tourists, improve the tourism attractiveness of Mount Wutai, promote the development of Mount Wutai tourism, and promote the protection and development of Mount Wutai with tourism.

\subsection{Strengthen the links with other tourist places and promote regional tourism integration.}

Shanxi Province has a long history and rich tourism resources. Mount Wutai should strengthen the connection with other tourist places in the province to promote regional tourism integration, increase tourism income and promote the protection and development of Mount Wutai.

\section{CONCLUSION}

World cultural landscape heritage represents "the common work of nature and mankind" ${ }^{[2]}$, with rich scientific, historical, cultural and tourist values, and is a major destination for tourism, and tourism in heritage sites is also a major tool for economic development. Mount Wutai is a cultural landscape heritage as well as a famous tourist destination in China. Through research and analysis, the current tourism situation of Mount Wutai is found to have obvious shortcomings, and in response to the existing problems, corresponding measures should be taken to protect and sustain the development of Wutai Mountain cultural landscape heritage driven by tourism ${ }^{[13]}$.

Mount Wutai is one of the earliest sites on earth to be exposed to water and has preserved a large number of geological relics ${ }^{[2]}$, and as a sacred Buddhist mountain, it has preserved a large number of Buddhist architecture and artworks from various periods. Although this paper proposes suggestions for the conservation and development of Mount Wutai, other heritage sites can also learn from the experience and suggestions to promote their own conservation and development.

\section{ACKNOWLEDGMENTS}

I would like to thank Professor Sun Keqin of China University of Geosciences (Beijing) for his guidance of this paper.

\section{REFERENCES}

[1] Ling B.X. (2013). Study on Protection of the World Heritage cultural landscape of Mount Wutai. (Doctoral dissertation, China University of Geosciences (Beijing)).

[2] Sun K.Q. (2020). World Heritage. Beijing:Peking University Press.

[3] Sun K.Q. (2012). Introduction to World Cultural and Natural Heritage. Beijing: China University of Geosciences Press.

[4] Wang J.L. (2019). Study on the Sustainable Development of World Cultural Landscape Heritage in Wutai Mountain. (Doctoral dissertation, China University of Geosciences (Beijing)).

[5] Wang D.D., Zheng Q.G., Hou Y.J., Gou C.Y. (2017). Characteristics of cultural landscape heritage and conservation measures in Wutai Mountain. Journal of Xinzhou Normal College., 33(04):20-23.

[6] Sun Z.L., Xu S.Z., He W.I.,,Pan Y.S. (2012). Characteristics and formation conditions of geological relics in Wutai Mountain National Geopark. North China Land and Resources., (06):99-102+104.

[7] Han Y., Bai M., Feng W.Y., Li X.Y., Zhang H., Wang Z. (2015). Research on tourism resources development of Wutai Mountain National Geological Park. Journal of Changchun Normal University., 34(10):88-93.

[8] Wu P.S., Ge X.I., Wang C. (2018). Research on offseason tourism development in Wutai Mountain. Journal of Xinzhou Normal College., 34(02):17-22.

[9] Zhao P.Y., Feng W.Y., Zhang H., Wang X.W. (2015). Research on the image perception of world cultural 
landscape heritage type tourist destinations--Wutai Mountain as an example. Journal of Central South University of Forestry Science and Technology (Social Science Edition). ,9(04):44-49.

[10] Cao R.J. (2015). Architectural layout and spatial organization of temples in Wutai Mountain, Shanxi. (Doctoral dissertation, Taiyuan University of Technology).

[11] Wang Z.Z. (2018). Research on the structure of domestic visitor source and visitor behavior of Wutai Mountain Scenic Area. (Doctoral dissertation, Shanxi Normal University).

[12] Liu S.P. (2018). Research on the optimization of tourism product structure of Wutai Mountain. (Doctoral dissertation, Shanxi University).

[13] Du, L.F. (2018). Research on sustainable development of ecotourism in Wutai Mountain Scenic Area. (Doctoral dissertation, East China Normal University).

[14] Jia S.Y., Feng W.Y., Chu X.C. (2015). Research on the construction of tourism website of tourism destination--Wutai Mountain tourism website as an example. Journal of Shanxi Normal University (Natural Science Edition). ,29(04):109-113. 